\title{
THE BOTTOM LINE
}

\section{Partha Kar: Rebalancing society's perceptions}

\author{
Partha Kar consultant in diabetes and endocrinology \\ Portsmouth Hospitals NHS Trust
}

It's a fascinating dichotomy: is a doctor a god or a servant? Colleagues talk about "all powerful" doctors of the past—who knew everyone, who blew people away with their knowledge, skills, and arrogance. They were healers, they told patients what to do, and patients did what they said. They told nurses what to do, and it happened. This perception, which led some patients to put doctors on a pedestal, was built up by years of media portrayals and, perhaps, bluster and self aggrandisation by doctors themselves.

But times changed, and the world changed. Patients found their voice-quite rightly, too. They became more inquisitive about their care, and they tried to find out more about why it may have faltered. Then they found their medical heroes, self styled or otherwise, wanting-making the same errors and being susceptible to the same foibles as anyone else. As happens when any of us sees the failings of those we admire, obeisance turned to disappointment, and in some cases that disappointment turned to anger, either towards individual doctors or towards the medical establishment.

The media still play a huge role in determining the public's view of doctors. But, as public perceptions have changed, so has the media's portrayal of the profession. Yes, television programmes still love to show consultants as charming and attractive individuals who sweep people off their feet, but the George Clooneys and Patrick Dempseys have also been fallible: they displayed emotions and made mistakes.

Patients and doctors themselves need to remember that doctors have the same needs and foibles, angst and empathy, and passion and tiredness as anyone else. They have the same desire to sit down with their families at the end of day, to enjoy the latest Netflix series, to be silly with their children, and to go out with their friends to enjoy a drink or two.
They have also been trained to do a specific job and, in the NHS at least, are paid to do so by the taxpayer. So, what about the notion of them being servants to the taxpayer or to patients? NHS doctors may be public servants in the literal sense that they're employed on behalf of a government. But describing someone as a servant implies having lesser rights than others or having to serve a master. Doctors certainly don't serve members of the public in this sense.

Many doctors like to label themselves as servants, public servants, or servant leaders. For me, however, such labels create an unhelpful view of the profession and can risk smearing doctors who are struggling to balance the everyday pressures of their jobs with their own lives.

Taxpayers fund our wages, but we're not accountable to individual taxpayers, and we shouldn't use a title that creates the illusion that we are. We should remember the words of the former French president Charles de Gaulle when he said, "In order to become the master, the politician poses as the servant." Doctors must treat patients with respect and engage with them, and a reciprocal approach from society would help us all. People must be able to see doctors as professionals who, in the main, have a passion and desire to improve patient care and who are trying to do their jobs as best they can-with the resources at their disposal.

Competing interests: I am associate national clinical director for diabetes with NHS England.

Provenance and peer review: Commissioned; not externally peer reviewed.

Published by the BMJ Publishing Group Limited. For permission to use (where not already granted under a licence) please go to http://group.bmj.com/group/rights-licensing/ permissions 